\title{
Jumaluste lemmikloomad ja ennustamine elundite põhjal
}

Enn Ernits

\begin{abstract}
Teesid
Saatuse, haiguse kulu, ilmade jm ennustamist on peetud alati tähtsaks. Olulisel kohal mantikas ehk ennustamiskunstis oli kogu maailmas ohvrilooma kui jumaluste lemmiku sisikonna ja luude põhjal ennustamine. Peamiselt mäletsejaliste ja teiste imetajate maksa, harvem südame ja kopsude muutuste alusel ennustasid näiteks etruski haruspeksid. Enne kiilkirja dešifreerimist võis tähelepanelik lugeja Babüloonia hepatoskoopiast teada saada piibli vahendusel. Ninive raamatukogust leitud tekstid sisaldavad üle kümne maksatermini. Babüloonia ende protaasis käsitleti maksa individuaalseid iseärasusi ja patoloogilisi muutusi (irdumine, verevalumid jm), larvotsüste ning väärarendeid. Mida haruldasem oli maksa muutus, seda kaalukam oli apodoos. Vana-Hiinas ennustati imetajate luude ja kilpkonna kilbi pragude põhjal. Laialdaselt oli varem kasutusel omoplatoskoopia ehk ennustamine abaluu järgi (nt Põhja-Ameerikas, Iirimaal, Siberis, Mongoolias, Hiinas).
\end{abstract}

Märksõnad: Babüloonia, ennustamine, loomamaks, loomapõrn, kilpkonna kilp, maksamudelid, mantika, ohvriloom

Aegade vältel on käekäigu, haiguse kulu, ilmade jm ennustamist peetud üsna tähtsaks. Kunsti tulevikku aimata ja jumalate ettekirjutisi teada saada nimetatakse mantikaks. See on tuletatud kreeka samatähenduslikust sõnast mantikē. Antiikkreeklased kasutasid ennustamiskunsti ja -annete tähistamiseks mitut sõna, nimelt manteía, mantosýnē ja prógnōsis. Ka ennustajate eristamiseks oli mitu nimetust: mántis, prophētēs jt (Liddel \& Scott 1982: 1079, 1473). Siinkohal mainime üksnes, et enamasti prognoosisid arstid, kelle maine kujundas just haiguste kulu õige ennustamise oskus.

Roomlased kutsusid ennustamist dīvīnātioks, mis seondub sõnaga divus 'jumal, jumalik'. Olulisel kohal mantikas oli laialdaselt kogu maailmas ohvrilooma kui jumaluste lemmiku sisikonna ja luude põhjal ennustamine vähemalt antiikajast alates, ent leidub ka mälestisi, mis näivad viitavat hämarasse esiaega.

http://haldjas.folklore.ee/tagused/nr31/ernits.pdf 
Enn Ernits

\section{Siseelundite järgi ennustamine}

Rohkesti on andmeid imetajate, eriti mäletsejaliste sisikonna põhjal ennustamise kohta antiikajast alates. Vana-Kreekas kutsuti ohvrilooma tapjat ja siseelundite põhjal ennustajat hiereús. See on ühenduses sõnadega hierós 'püha; jumalale pühendatud; jumalik' ja hiereíon 'ohvriloom'. Ohvriloomavaatlejat nimetati ka hieroskóposeks või hieróptēseks (Frisk 1973: 712-713; Liddel \& Scott 1982: 821-822). Teadaolevalt polnud Vana-Kreekas loomade sisikonna järgi ennustamine siiski sedavõrd levinud kui Rooma riigis, kus oli tunda tugevaid etruski mõjutusi.

Ennustajatena olid eriti hinnatud etruski preestrid (netsviś), keda roomlased kutsusid harūspexideks. Neid teati Roomas juba 6. sajandi alguses eKr viimase etruski kuninga Tarquinus Suberbuse valitsuse ajast peale. Haruspekse hakati alates 3 . sajandist eKr

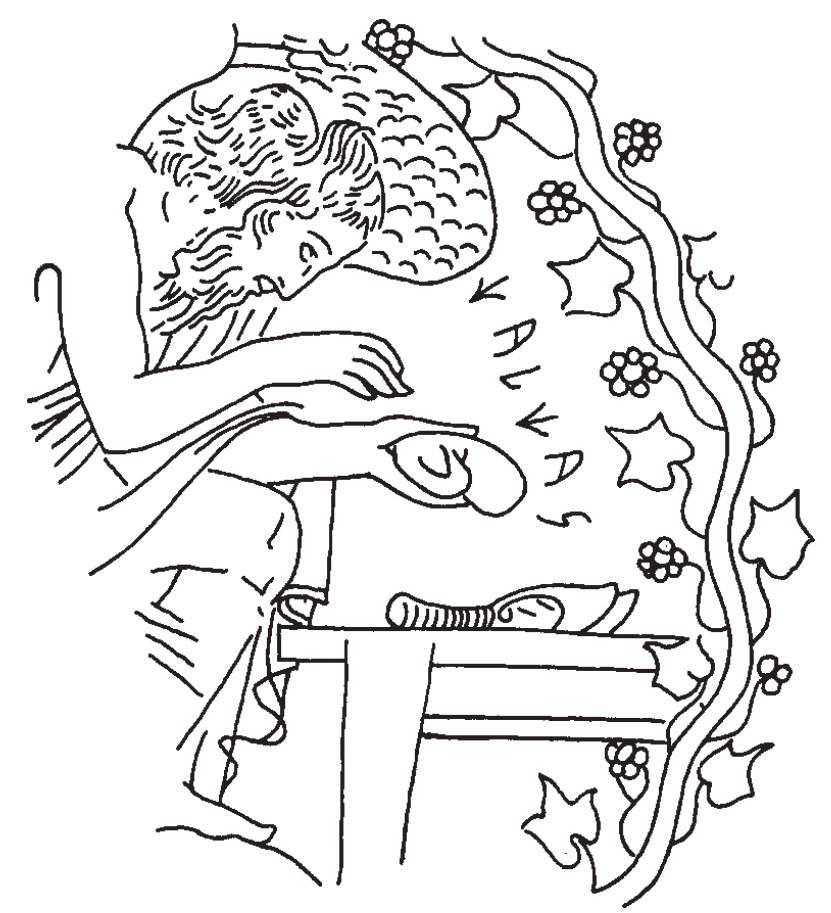

Joonis 1. Etruski ennustaja Vulci peeglilt (Scharf 1988: 13). 
kutsuma ennustama ka pealinna, kuid nende ended pidid saama senati kinnituse. Haruspeksid seletasid ja tõlgendasid jumalate tahet peamiselt ohvrikanade ja -veiste maksa järgi. Nad polnud üksnes ohvrilooma vaatlejad. Nad valdasid kogu ennustuskunsti, mida roomlased nimetasid disciplina Etruscaks. See oli kirja pandud mitmeosalises teoses, mis kajastas sisikonna, väärarendite ja välkude vaatlust ning muid endeid (vt Irmscher 1972: 137, 222). Asjaomase teose tõlkisid roomlased ladina keelde, sh käesoleva teema seisukohalt huvitavad osad nimetuse Libri haruspicini (Sisikonna ennustuskunsti raamatud) all. Paraku pole originaal ega tõlge tänaseni säilinud.

Ennustuskunsti nimetati Vana-Roomas ka extispicium (exta 'sisikond' järgi). Haruspeksidest Vana-Roomas on teateid viimati veel 6. sajandist pKr, enne kristluse pealetungi (Zompro 1999).

Sisikonnavaatluse olevat etruskidele lähetanud jumalad. Talupoeg kündnud kogemata tavalisest sügavama vao, kust roninud välja tarkusejumal kääbus Tages. Kündja ehmatuskarjete peale kogunenud palju rahvast. Neile olevat Tages õpetanud ennustamiskunsti, mis hiljem pandud kirja pühadesse raamatutesse. Rooma oraator, poliitik ja kirjamees Marcus Tullius Cicero (106-43 eKr) suhtus haruspeksidesse skeptiliselt:

Kas on keegi nii rumal, et usuks, et künti välja - kuidas ma peaksin ütlema? - kas jumal või inimene? Kui jumal, miks ta siis vastu ootusi oli end maa sisse peitnud [---]. Oli see Tages aga inimene, kuidas oleks ta saanud maa all elada? [---] Ma tean väga hästi Cato ammuaegset ütlust, et paneb imestama, miks haruspeks ei naera iialgi siis, kui ta näeb haruspeksi: kui palju on nende ennustustest täide läinud? (Burian \& Mouchová 1973: 134-135).

Etruski ennustajad vaatlesid peamiselt ohvrilooma maksa, harvem südant ja kopse. Ohverdati tavaliselt veiseid, kes pidid olema terved ega tohtinud tõrkuda, kui neid ohvrialtarile toodi.

Etruski ennustajast saame aimu ühe gravüüri järgi. See leidub Vulcist avastatud pronkspeeglil 4. sajandist eKr (joonis 1). Gravüüril on näha preestrit kummardumas laua kohale, millel asetsevad hingetoru ja kopsud. Ennustaja hoiab vasakus käes maksa ja silmitseb selle vistseraalset (sisikonnapoolset) pinda. Vasakul sagaral paistab sabajätke, mis on Saksa anatoomil Joachim-Hermann Scharfil (1988: 13) võimaldanud oletada teratoloogia valdkonda kuuluvat 


\section{Enn Ernits}

äraspidist asetust (situs inversus). Pronkspeeglile on kirjutatud halhas. Seda sõna võrreldakse Trooja sõja aegse kreeka ennustaja Kalhase nimega. On ju etruski jumalanimedeski palju kreeka laene. Volterra hauakambrist on avastatud alabastrist urnikaas, millel on kujutatud haruspeksi hauakambrikülastaja suunas maksa ulatamas.

Maksavaatlust ehk hepatoskoopiat õppisid etruskid tõenäoliselt mudelite varal. 1877. aastal leiti kündmisel Põhja-Itaaliast Piacenza lähedal juhuslikult väga haruldane ese - pronksist lambamaks (joonis 2). Selle vistseraalne pind on jagatud sektoriteks, millelt võib lugeda heade ja pahade jumaluste nimesid (joonis 3 ). Kirjatähtede kuju lubab väita, et maksa koopia on valmistatud 3. sajandil eKr või hiljem (Burian \& Mouchová 1973: 129).

Maksamudelil saab eristada vaid vasakut ja paremat sagarat, sest tollal saba- ja ruutsagarat vist omaette alaosadena ei käsitletud. Näha on maksa-ümarsideme lõhe, mille läheduses kummub sapipõis. Paremal pool kõrgub püramiidjalt sabajätke, mida veel keskajal kutsuti processus pyramidaliseks ('püramiidjätke') ja caput iocineriseks, sellest vasakul aga näsajätke. Kahjuks pole maksa alaosade etruskikeelsed nimetused meie ajani säilinud. Maksa koopia diafragmapinnal on punktidega tähistatud maksa-ümarsideme kinnitumise ja kaudaalse õonesveeni läbimise koht. Peaaegu risti üle maksa kulgeb topeltjoon, mida on seostatud sirpsidemega.

Etruskide etnilise päritolu üle on palju vaieldud. Osa uurijaid arvab, et nad on Apenniini poolsaarele rännanud Väike-Aasiast. Pälvib tähelepanu, et etruski pronksmaksa sarnaseid figuure tehti ka Väi-

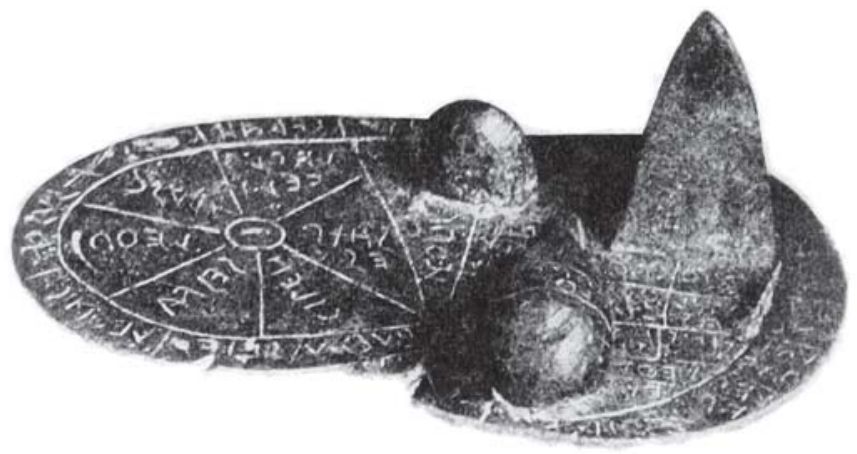

Joonis 2. Etruski maksamudel (Burian \& Mouchová 1973). 


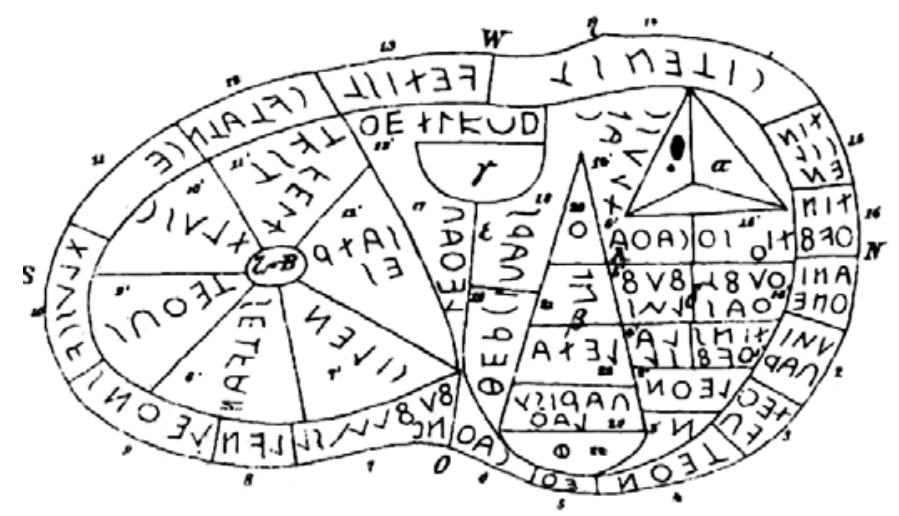

Joonis 3. Etruski maksamudeli vistseraalne pind jumaluste nimedega (Scharf 1988: 15).

ke-Aasias laiunud Hetiidi riigis, tõsi küll, savist. See võimaldas oletada etruskide sidemeid Idamaadega, ent see pole päris kindel.

Kunagine Tartu ülikooli anatoomiaprofessor Christian Hermann Ludwig Stieda (1837-1918) võrdles etruski maksafiguure tuhatkond aastat vanema Mesopotaamia leiuga, leides nende vahel sarnasusi (Ludwig Stieda, Grundriss der Anatomie des Menschen, Hannover: Jänecke 1900; tsit: Scharf 1988: 4). Ka tänapäeval väidab osa uurijaid, et hepatoskoopia pärineb Babülooniast. Sealt olevat maksavaatluskunst levinud hetiitide vahendusel Kreekasse ja Etruuriasse. Teatakse, et Babüloonia territooriumil varem paiknenud Sumeris riiklikul tasemel ennustamisega ei tegeldud (Freydank et al. 1978: 276).

Hepatoskoopia oli eriti moes Assüüria kuninga Aššur-aha-iddina ja ta poja Aššur-ban-apli valitsemisaegadel aastatel 680-627 eKr. Viimane rajas Nīnās (Ninive, tänapäeva Kuyunçik) suure raamatukogu. Selle väljakaevamisel avastati kataloog, mis kajastas kaht mantikakogu (kokku 31 savitahvlit), sh ka maksavaatluse kohta (Bezold 1926: 104). Rohkesti on hepatoskoopilisi tekste nii Nīnāst kui ka mujalt. Näiteks ühte neist hoitakse praegu Berliini Aasia Muuseumis. Selle on kopeerinud uusassüüria kiilkirjamärkidega vanababüloonia keeles Aššuri linna kirjutaja poeg Nabiu-êțir. Originaal võis olla loodud umbes aastal $2000 \mathrm{eKr}$. Seega on võimalik, et assüüria teadmised põlvnesid naaberriigi Babüloonia vanemast perioodist. 


\section{Enn Ernits}

Enne kiilkirja dešifreerimist võis tähelepanelik lugeja Babüloonia hepatoskoopiast teada saada piibli vahendusel. Nimelt on Vana Testamendi Hesekieli raamatus kirja pandud:

Sest Paabeli kuningas seisab teelahkmel, mõlemate teede alguses, liisku heites: ta raputab nooli, küsitleb teeraveid, uurib maksa! (Hs. 21: 26)

Babüloonias uuriti põhiliselt äsjatapetud lamba sisikonda, kusjuures pöörati tähelepanu elundite asenditele, soolelingudele jm (Scharf 1988: 11 jj). Erilise tähendusega elundiks peeti maksa (vanababüloonia amūtum). Ka babüloonlased on hepatoskoopia põhitõdede õppimisel kasutanud ilmselt maksamudeleid. Üht tervet perioodist 20.-16. sajand eKr pärinevat maksakoopiat säilitatakse Briti muuseumis (joonis 4). See meenutab etruski pronksmaksa sapipõie, sabaja näsajätkega. Mujal säilitatakse teisigi maksamulaaže, kuid enamasti suuremate või väiksemate fragmentidena.

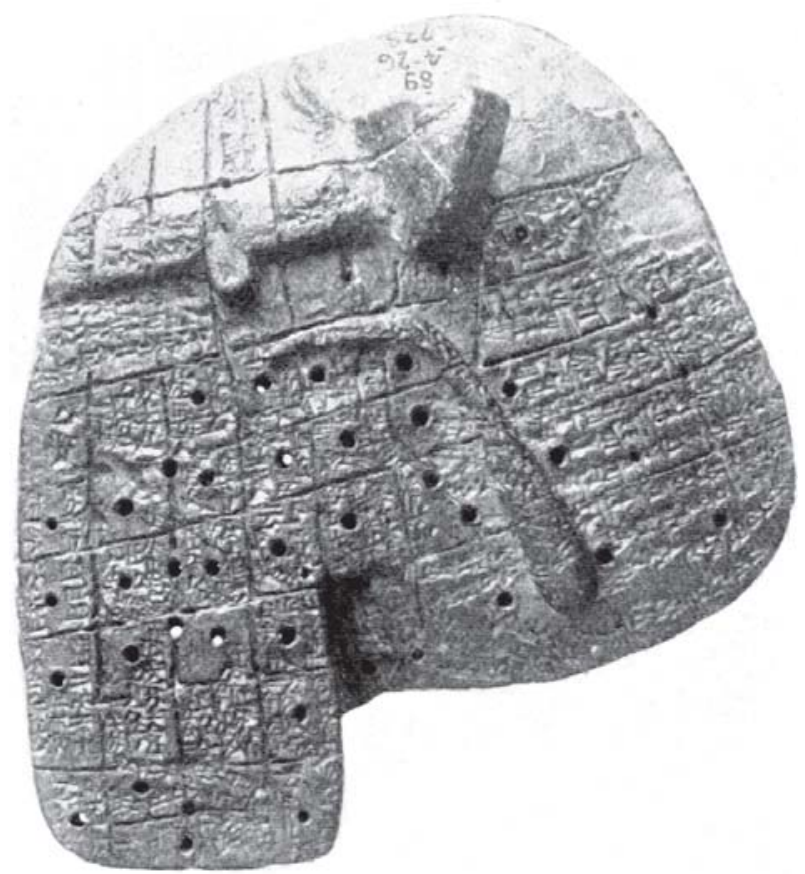

Joonis 4. Vanababüloonia maksamudel (Bezold 1926: 126). 
Teadaolevail andmeil pole savitahvlitel normaalset maksa kirjeldatud, ilmselt oli selle ehitus ennustajal (bārum) mällu talletatud. Tekstide põhjal on üritatud taastada, kuigi ebakindlalt, maksaalast terminoloogiat ja saadud tublisti üle kümne nimetuse.

Babüloonlased jagasid maksa kaheks pooleks (sagaraks) - vasakuks (šumēlum) ja paremaks (immitum). Sabasagaral (išdi ubānum) kirjeldati sabajätket (ubānum; rēš amamūtim) ja näsajätket (șibtum). Eristati maksaväratit (abullum), maksa-ümarsideme lõhet (biritum) ja sälku ( $b a ̄ b$ ekallim; sõna-sõnalt 'paleevärav'). Detailselt kirjeldati sapipõit (martum), millel eristati kaela (qutun martim), lehtrit (ruqqu ša martim), keha (appum; sihitavas käändes) ja põhja (rēš martim). Sapisüsteemi osadest tunti veel ühissapijuha (padānum) ja sapipõiejuha (maşra martim). Dešifreerida on püütud ka maksasidemete nimetusi, kuid üpris ebausutavalt.

Babüloonia enne koosnes a) protaasist, mis algas sõnaga kui, ja b) apodoosist (siis...). Protaasis käsitleti maksa individuaalseid ja patoloogilisi muutusi (irdumine, verevalumid jm), larvotsüste ning väärarendeid.

Mida haruldasem oli maksa muutus, seda kaalukam oli apodoos. Näiteks üliharvaks võib pidada ühissapijuha kaasasündinud sopistist, mis kuulutas haruharva esinevat juhtumit, nimelt vaenlase sõjaväe täielikku hävimist - see tähendas sisuliselt ju riigi lakkamist. Sageli kajastus ennetes pseudoanaloogia. Näiteks sapipõiejuha laienemise põhjal kuulutati, et "maa saavutab oma eesmärgi". Laienemine võimaldab rohkem sappi läbi voolata, mis võrdub ideega "tee eesmärgile on lahti".

Nīnā raamatukogust on leitud 6. sajandist eKr pärinev 24 savitahvlile kirjutatud ennetekogu. See sisaldab andmeid üle 2000 väärarendi kohta. Mõned neist esinevad ka looduses, osa on aga puhtalt fantaasiavili (Schäffer 1988, tsit Driesch \& Peters 2003: 23 järgi).

Tuntud eesti fenoloog Vadim Želnin kasutas talvede ennustamisel seapõrna:

Kui põrna esiosa on paks (vahel kuni $5 \mathrm{~cm}$ ), siis on külm ja lumine talve esimene pool, kui aga lõpuosa, siis teine pool (Želnin (1985: 82).

Ta nentis, et juba vanasti jälginud talumehed sügisese seatapu ajal põrna. Ka keeleteadlane Ferdinand Johann Wiedemann (1876) on eesti talupoegadelt kirja pannud seose seapõrna eesosa paksuse ja talve algupoole lumekuse vahel. Samasugusest ennustamisest on 


\section{Enn Ernits}

teateid ka Soomest. Etnoloog Kustaa Vilkuna (1950: 278) on kirjutanud, et sea põrn jagati mõtteliselt nii paljudeks nädalateks või kuudeks, kui palju neid oli talvise ja suvise pööripäeva vahel. Kraniaalse põrnaotsa alusel ennustati lume hulka sügistalvel. Kõrgemad kohad põrnakoes osutanud aga suuremate lumesadude aega. Seevastu Saksamaal arvasid Brandenburgi talunikud 19. sajandil, et tapetud sea äraspidise kujuga põrn tähendab olulist pööret inimese elus, nimelt omaste surma lähemal ajal (Tylor 1989: 99).

Soomlased ja saamid ennustasid ilma havimaksa järgi. Sel puhul võib täheldada täielikku analoogiat põrna pealt prognoosimisega: kui maksa eesosa oli õhuke, arvati tulevat kuiv suvi, kui aga paks, siis vihmane. Inari järve äärsed saamid väitsid, et kui maksa eesosas leidub rohkesti veresooni, tulevat kevad ja suve algupool jahedad, kui neid on aga palju elundi tagaosas, on oodata külma sügist; kui kogu maks sisaldab rikkalikku soonestikku, olevat kogu suvi jahe; veresoonte nähtamatus osutavat aga päikesepaistelisele suvele. Saamid ennustasid lumekust lambamao põhjal. Kui vatsa limaskestalt leiti vähe näsasid, kuulutanud see lumevaest talve (Toivonen 1956: 144-145).

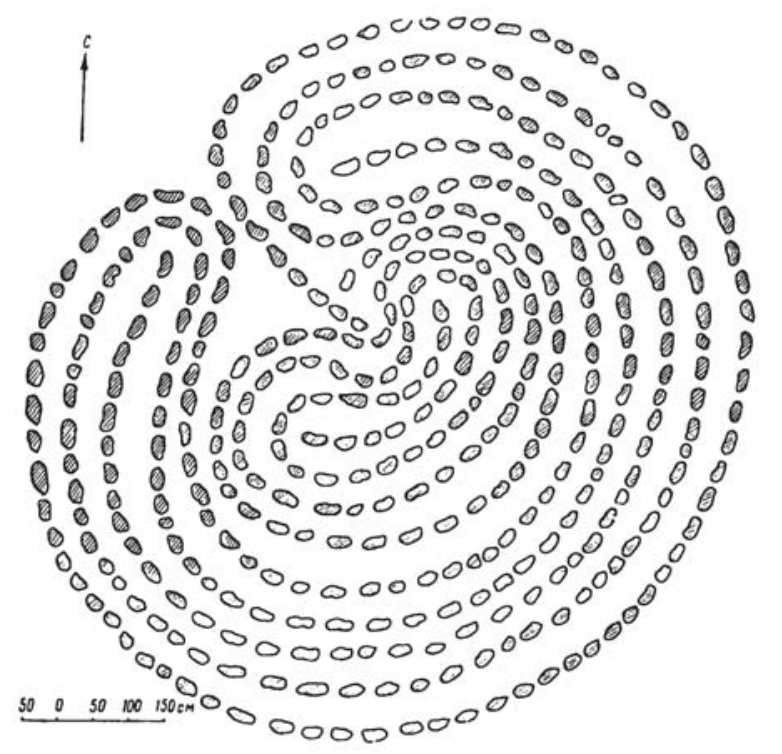

Joonis 5. Umba kivilabürint Koola poolsaarel (Gurina 1953: 412). 
Enn Ernits

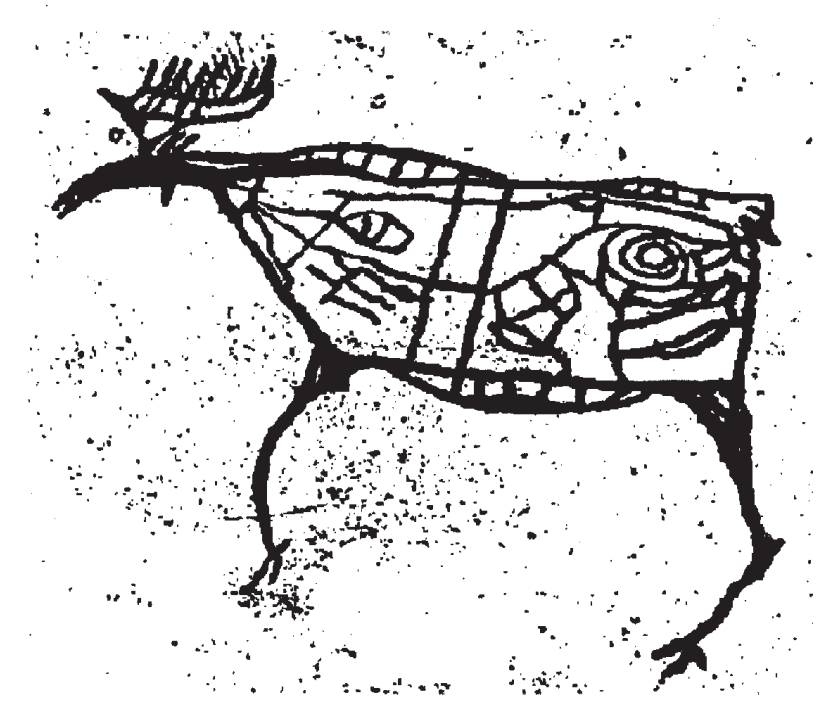

Joonis 6. Nn röntgenistiilis muinasaegne põdraraiend Åskollenist Norras.

Looma siseelundite muutuste järgi ennustasid paljud loodusrahvad. See oli varem laialdaselt levinud näiteks malailastel, polüneeslastel, inkadel jt. Kesk-Aafrikast on teada, et nõid tappis ja lahkas ennustamiseks kana, keda uuriti põhjalikult seest- ja väljastpoolt. Kui tiibade kohalt leiti mõni vigastus, ennustanud see reetmist laste või sugulaste poolt. Seljaluu paljastas ema või vanaema, saba aga naise kuritegu (Tylor 1989: 99).

Ka soolestiku iseärasusi on kasutatud ennustamisel. Põhjamaadest on teada sadu munakividest laotud eri tüüpi labürinte (joonis 5). Neid rajati arheoloogide teatel II aastatuhandest eKr kuni II aastatuhande alguseni pKr. Oletatakse, et rajatisi on teinud saamide esivanemad. Kivilabürintide muistne otstarve pole päris selge. Etnoloog Vladimir Tšarnoluski (1972: 87) meenutas 1920. aastatel peetud Koola saamide ohvripeо лыхте-верра kohta järgmist. See toimunud metsas suure, kujult põhjapõdra pead meenutava rändrahnu juures Meandaši auks. Pärast ohvrilooma söömist keksinud šamaan ühel jalal läheduses asuva labürindi kivide vahel selle keskpaiga suunas. Seejuures ennustatud ilma, jahiõnne, haiguse kulgu jm. Hüplemisel jälgiti, millised tõigad räägivad võimalikust edust ja õnnest, millised aga mitte. Peetakse tõenäoliseks, et 


\section{Enn Ernits}

labürinte kasutati mantilisel või maagilisel otstarbel ka muiste. Huvitav on lisada, et orientalist Eberhard Hommel (Zur Geschichte des Labyrinths, Orientalische Literaturzeitung 22 (maalis-huhtikuu), 1919; tsit Viik 1990: 53 järgi) pidas neid ohvrilooma soolestiku mudeliks. Rajatis meenutab tõepoolest mäletsejaliste käärsooleketast. Sel juhul osutab see loomasoolestiku põhjal ennustamisele kauges minevikus. Labürinti meenutavat soolestikku on muistsed kütid nii Skandinaavias kui ka Siberis rõhutanud ka põtra kujutavatel kaljujoonistel (joonis 6).

\section{Luude ja luukilpide järgi ennustamine}

Vana-Hiinas on ennustamiskohtades leitud III aastatuhande teisest poolest alates imetajate luid ja kilpkonnakilpe. Põhja-Hiina antiikse kuningaresidentsi Anyangi (16.-11. saj eKr) arheoloogilistel kaevamistel leitud luud (enamasti abaluud) pärinevad põhiliselt veiselt, harvem hirvelt, lambalt, sealt ja hobuselt. Kilpkonnakilpe kasutati Lõuna-Hiinas. Luusse või kilpi tehti sälk ja selle kõrvale puuriti auk. Seejärel hoiti luud või kilpi tule kohal, kusjuures tekkis üks pikem ja teine, sellega risti kulgev pragu, mille kuju järgi ennustati tulevikku (Freydank et al. 1978: 328).

Ennustamist abaluu põhjal nimetatakse omoplatoskoopiaks ehk skapulimantiaks. Varem oli see maailmas üsna laialdaselt levinud. Näiteks Põhja-Ameerika indiaanlased kuumutasid lõkketulel okassea abaluud, mille värvuse muutuste järgi ennustati jahiõnne. Sama elundit kasutati ennustamiseks ka Inglismaal. Iirimaal ennustati jäära parempoolse abaluu abil nii kauget minevikku kui ka tulevikku. 19. sajandi inglise etnoloogi Eduard Burnett Tylori (1989: 99) oletusel võis see tava olla sinna levinud Mongooliast, kus oli omakorda seondunud vanahiina ennustamiskunstiga. Omoplatoskoopia ülemaailmne levik ainukoldest tundub siiski ebausutavana. Kindlasti tuleb ühe olulise eraldi koldena arvesse Mongoolia ja seda ümbritsevad alad (Siber, Hiina). Omoplatoskoopia oli kasutusel paljudel altai rahvastel.

Saksa looduseuurija Peter Simon Pallas (1741-1811) rändas 18. sajandi teisel poolel Peterburi Teaduste Akadeemia ülesandel kogu Venemaal. Siberis kirjeldas ta muu hulgas ka omoplatoskoopiat. Tema andmetel hoiti abaluud tulel pragunemiseni. Pikipragu tähendanud eluteed, ristipraod aga mitmesuguseid häid 
Enn Ernits

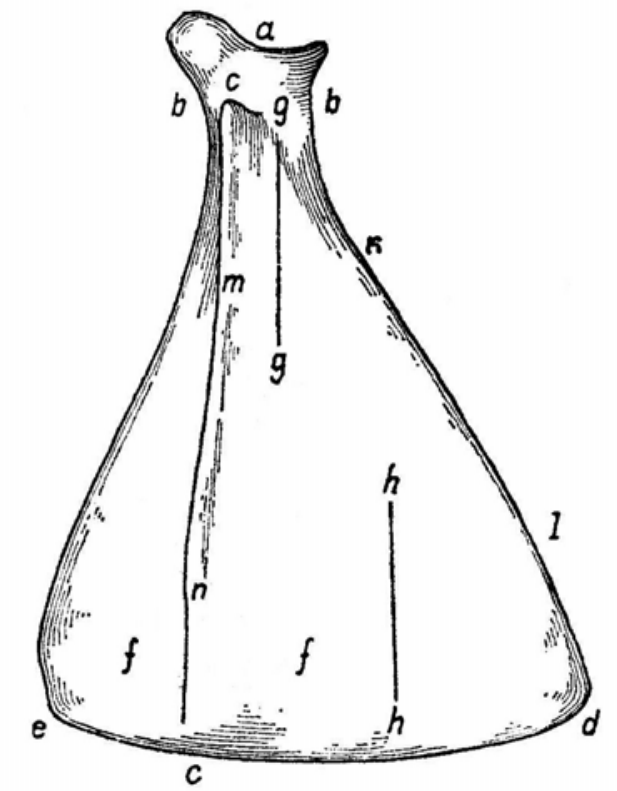

Joonis 7. Lamba abaluu Grigori Potanini (Radloff 1989:

305) järgi. Täiendatult ümber joonistanud Eha Järv.

Tabel. Kasahhi abaluuleksikat Grigori Potanini (Radloff 1989: 306) järgi.

\begin{tabular}{|c|c|c|c|c|}
\hline \multicolumn{3}{|c|}{ ABALUU ALAOSAD } & \multicolumn{2}{|r|}{ ENDERÜHMAD } \\
\hline $\begin{array}{c}\text { Tähis } \\
\text { joonisel }\end{array}$ & \begin{tabular}{|c|} 
Kasahhi vaste \\
ja tõlge
\end{tabular} & Eesti vaste & $\begin{array}{c}\text { Tähis } \\
\text { joonisel }\end{array}$ & Kasahhi vaste ja tõlge \\
\hline$a$ & казан 'katel' & liigeseõõnis & $b d$ & кара джол 'peatee' \\
\hline $\mathrm{bb}$ & бауздау & abaluukael & $g g$ & $\begin{array}{c}\text { куискан 'sabarihm', st } \\
\text { paralleelsed praod piki } \\
\text { harja }\end{array}$ \\
\hline be & кыр 'serv' & kraniaalne serv & hh & тил 'teade' \\
\hline $\mathrm{cc}$ & & abaluuhari & k & $\begin{array}{c}\text { джакын ӓлдӓги джол 'tee } \\
\text { lähedaste inimestega' }\end{array}$ \\
\hline$d$ & кулак 'kõrv' & kaudaalne nurk & 1 & $\begin{array}{l}\text { алыс ӓлдӓги джол 'tee } \\
\text { kaugete inimestega' }\end{array}$ \\
\hline e & мангдай'ots mik' & kraniaalne nurk & $\mathrm{m}$ & сӱиншӱ 'hea uudis' \\
\hline$f$ & $\begin{array}{l}\text { джаурундынг } \\
\text { этӓги'tagaosa' }\end{array}$ & harjaalune auk & $n$ & aт ayz'hobuse suu' \\
\hline
\end{tabular}




\section{Enn Ernits}

ja kurjakuulutavaid endeid. Kui prognoositi mingit kindlat sündmust, siis peeti heaks märgiks üksnes pikilõhesid (Tylor 1989: 99).

Kasahhide omoplatoskoopiat on ülemöödunud aastasajal kirjeldanud vene uurija Grigori Potanin (1835-1920) ja saksa rahvusest turkoloog Friedrich Wilhelm Radloff (ka Radlov, 1837-1918). Kasahhid puhastanud ennustamiseks kõigepealt lamba abaluu loitsu saatel. Seejuures ei tohtinud luud vigastada. Tulel kuumutatud abaluu pragudest otsiti varast, kadumaläinud hobuseid ja muud. Abaluul (джаурум) eristati vähemalt seitset alaosa ja rida piirkondi, millel tekkinud lõhed väljendasid erinevaid enderühmi (Radloff 1989: 305-306).

Ilmneb, et kasahhidel oli abaluu ehituse kirjeldamiseks üpris detailne sõnavara (vt tabel). Joonisel 7 on kujutatud parempoolset abaluud. On ju ootuspärane, et parempoolne ennustas kas paremini või paremat tulevikku. Joonis ja kommentaarid nurkade kohta (vasak ja parem) näitavad, kuidas ennustaja hoidis abaluud käes, nimelt abaluukõhr allpool ja kraniaalne serv vasakul.

Ka altailased ja tõvalased ennustasid lamba abaluu varal. Jakuudid kasutasid põhjapõdra abaluud tegemaks kindlaks, kas sõidu jätkamine on otstarbekas. Nimetatud elundi abil ennustajat kutsusid kasahhid джаурунджў ja krimmitatarlased джаурынджы, tõvalased чарынчы ja teised turgi rahvad чарыны. Mongolitel tähistab lamba abaluu abil ennustajat далуч, mis on tekkinud samuti luu nimetusest, vrd далу 'abaluu'. Mongoli keelest on nii abaluu kui ka abaluu järgi ennustaja nimetus siirdunud evengi keelde (Radloff 1911: 8; Levitskaja 1989: 66-67; Dõbo 1996: 139-140, 222, 251). Krimmitatarlaste esivanemad elasid esialgu Altais. Asjaomane nimetus näitab, et ennustamine abaluu põhjal võib olla levinud sealt Krimmi üsna varakult (alates 9 . sajandist $\mathrm{pKr}$ ).

Eriti 14.-12. sajandil eKr kasutati Hiinas peale pragude järgi ennustamise laialdaselt veel ennustamist nn oraakliluude või kilpidega, millele oli kirjalik tekst sisse kriibitud. Eespool nimetatud Anyangi väljakaevamisel on viimase saja aasta jooksul leitud üle 100000 sellise pealiskirja. Luudelt võib leida andmeid preestri nime, talle esitatud küsimuse, oraakli vastuse ja sündmuse täidemineku kohta. Preestrilt on küsitud endeid ilmastikunähtuste, reiside, jahi- ja sõjakäikude jm kohta (Freydank et al. 1978: 327). 


\section{Kirjandus}

Bezold, Carl 1926. Ninive und Babylon. 4., ümbertöötatud trükk. Monographien zur Weltgeschichte 18. Bielefeld \& Leipzig: Velhagen \& Klasing.

Burian, Jan \& Mouchová, Bohumila 1973. Etruskide kuulsus ja langus. Mosaiik. Tallinn: Valgus.

Driesch, Angela von den \& Peters Joris 2003. Geschichte der Tiermedizin: 5000 Jahre Tierheilkunde. 2., täiend tr. Stuttgart \& New York: Schattauer.

Dõbo 1996 = Дыбо, Анна В. 1996. Семантическая реконструкция в алтайской этимологии: Соматические термины (плечевой пояс). Москва: Языки русской культуры.

Freydank, Helmut \& Reineke, Walter F. \& Schetelich, Maria \& Thilo, Thomas 1978. Der Alte Orient in Stichworten . Leipzig: Koeler \& Amelang.

Frisk, Hjalmar 1973. Griechisches etymologisches Wörterbuch 1: A-K. 2. tr. Indogermanische Bibliothek: Zweite Reihe, Wörterbücher. Heidelberg: Carl Winter Universitätsverlag.

Gurina 1953 = Гурина, Нина Н. 1953. О датировке каменных лабиринтов Белого и Баренцова морей. Окладников, Алексей П. (toim). Палеолит и неолит СССР 53. Материалы и исследования по археологии С(оюза) ССР. Москва \& Ленинград: Издательство АН СССР, lk 408-420.

Irmscher, Johannes (toim) 1972. Lexikon der Antike. Leipzig: VEB Bibliographisches Institut.

Levitskaja 1989 = Левитская, Лия С. (toim) 1989. Этимологический словарь тюркских языков: Общетюркские и межтюркские основы на буквы "Ж”, “Й”. Москва: Наука.

Liddel, Henry George \& Scott, Robert 1982. A Greek-English Lexicon: With supplement, 1968. 9., täielik trükk. Oxford: Clarendon Press.

Radloff, Friedrich Wilhelm (= Радлов, Василий В.) 1911. Опытъ словаря тюркскихъ наречий IV: 1 = Versuch eines Wörterbuches der Türk-Dialekte IV: 1. St. Pétersbourg.

Radloff 1989 = Радлов, Василий В. Из Сибири: Страницы дневника. Этнографическая библиотека. Москва: Наука.

Scharf, Joachim-Hermann 1988. Anfänge von systematischer Anatomie und Teratologie im Alten Babylon. Sitzungsberichte der Sächsischer Akademie der Wissenschaften zu Leipzig: Mathematisch-naturwissenschaftliche Klasse 120: 3. Berlin: Akademie-Verlag.

Zompro, Andreas 1999. Haruspices. Das Schwarze Netz (http://www. sungaya.de/schwarz/romer/haruspices.htm - 12. detsember 2005). 


\section{Enn Ernits}

Želnin, Vadim. 1985. Läbi aastaaegade: [fenoloogilised vaatlused]. Tallinn: Valgus.

Toivonen, Yrjö Henrik 1956. Pohjanperien haruspex. Kalevalaseuran vuosikirja 36. Porvoo \& Helsinki: Söderström, lk 143-146.

Tšarnoluski 1972 = Чарнолуски, Владимир В. 1972. В краю летучего камня: записки этнографа. Москва: Мысль.

Tylor 1989 = Тайлор, Эдуард Бернетт 1989. Первобытная культура. Библиотека атеистической литературы. Москва: Издательство политической литературы.

Viik, Tõnu 1990. Labyrinths Around the Baltic. Swansongs: Rock Art from Lake Onega 4000-2000 B.C: Exhibition catalogue and reports = Joutsenen kynällä:Äänisen kalliotaidetta 4000-2000 eKr.: Näyttelykatalogi ja -esitelmat. [Tartu]: Estonian Society of Prehistoric Art, lk 51-54.

Vilkuna, Kustaa 1950. Vuotuinen ajantieto: Vanhoista merkkipäivistä sekä kansanomaisesta talous- ja sä̈̈kalenterista enteineen. Suomen tiedettä 11. Helsinki: Otava.

Wiedemann, Ferdinand Johann 1876. Aus dem inneren und äusseren Leben der Ehsten: Der Akademie vorgelegt am 30. Sept. 1875. St.-Petersburg: Keiserliche Akademie der Wissenschaften. 